Jurnal Agro Vol. III, No. 1, Juli 2016

\title{
PENINGKATAN PRODUKSI BAWANG MERAH MELALUI TEKNIK PEMUPUKAN NPK
}

\section{THE SHALLOT PRODUCTION INCREASE THROUGH NPK FERTILIZER TECHNIQUE}

\author{
Ida Nur Istina \\ Balai Pengkajian Teknologi Pertanian Riau \\ Korespondensi: idanuristina@gmail.com \\ Diterima 13 Juli 2016 / Disetujui 20 Juli 2016
}

\begin{abstract}
ABSTRAK
Bawang merah merupakan salah satu komoditas hortikultura strategis yang penyebarannya hampir di seluruh wilayah Indonesia. Permasalahan pengembangan komoditas ini adalah masih rendahnya produktivitas sebagai akibat adaptasi dan kecukupan asupan hara tanaman. Penelitian yang bertujuan untuk mendapatkan jenis pupuk NPK yang efektif dan efisien telah dilakukan di desa Langensari Kecamatan Lembang Kabupaten Bandung Barat dari Maret sampai Mei 2014 menggunakan Rancangan Acak kelompok (RAK) dengan 6 perlakuan dan 3 kali ulangan. Pupuk NPK yang digunakan adalah $A=N P K 18+9+10+T e, B=N P K 15+15+$ sulfat 10 , $\mathrm{C}=\mathrm{NPK} 12+11+18 \mathrm{z}+(\mathrm{S}) \mathrm{z}+3 \mathrm{Mg}+3,8 \mathrm{~S}+\mathrm{Te}, \mathrm{D}=\mathrm{NPK} 15+9+20(\mathrm{~S})+2 \mathrm{MgO}+3,8 \mathrm{~S}+\mathrm{Te}, \mathrm{E}=\mathrm{NPK} 25+7+7$ dan $\mathrm{F}=$ kontrol. Parameter yang diamati meliputi: tinggi tanaman, jumlah umbi, jumlah daun, panjang umbi $(\mathrm{cm})$, diameter umbi $(\mathrm{cm})$, bobot basah $(\mathrm{g})$ dan bobot kering brangkasan $(\mathrm{g})$. Hasil penelitian menunjukkan bahwa NPK $12+11+18 z+(S) z+3 \mathrm{Mg}+3,8 \mathrm{~S}+\mathrm{Te}$ menghasilkan bobot umbi terbaik.
\end{abstract}

Kata kunci : Bawang merah, NPK majemuk, Pertumbuhan dan produksi

\begin{abstract}
The shallot is one of the strategic and valuable horticultural commodities which is spreaded almost all over Indonesia area. Commodity development constrain by the low productivity as a result of adaptation and inadequate intake of plant nutrients. The research purposed to get the kind of NPK fertilizers that was efective and efficient on shallot production had been done in the Langensari village Langensari Lembang district, West Bandung regency from March till May 2014, using Randomized Block Design (RBD) with 6 treatments and 3 repplications. NPK fertilizer used were: $A=N P K 18+9+10+T e, B=N P K 15+15+$ sulfate $10, C=N P K 12+11+18 z+(S) z$ $+3 \mathrm{Mg}+3,8 \mathrm{~S}+\mathrm{Te}, \mathrm{D}=\mathrm{NPK} 15+9+20(\mathrm{~S})+2 \mathrm{MgO}+3,8 \mathrm{~S}+\mathrm{Te}, \mathrm{E}=\mathrm{NPK} 25+7+7$ and $\mathrm{F}=$ control. The observed parameters were plant height $(\mathrm{cm})$, number of tubers, leaf number, tuber length, tuber diameter, fresh weight and dry weight tuber. The results showed that NPK $12+11+18 z+$ (S) $z+3 \mathrm{Mg}+3,8 \mathrm{~S}+\mathrm{Te}$ gave the best growth and production.
\end{abstract}

Keywords : Growth and production, NPK compound, Shallots 


\section{PENDAHULUAN}

Bawang merah (Allium cepa var aggregatum) merupakan salah satu komodi-tas hortikultura unggulan dan memiliki prospek yang baik untuk pemenuhan konsumsi nasional, sumber pendapatan petani, dan devisa negara. Pentingnya komoditas ini tidak saja sebagai bumbu penyedap berkaitan dengan aromanya tetapi juga khasiat obat oleh kandungan enzim yang berperanan dalam meningkatkan derajat kesehatan, kandungan zat anti imflamasi, anti bakteri dan anti regenerasi.

Menurut Samadi dan Cahyono (2005), bawang merah dimanfaatkan untuk menyembuhkan penyakit maag, masuk angin, menurunkan kadar gula dalam darah, kolesterol, obat penyakit kencing manis, menghilangkan lendir dalam tenggorokan, memperlancar peredaran darah, menghambat penimbunan trombosit, dan meningkatkan aktivitas fibrinolitik karena bawang merah mengandung gizi cukup tinggi, setiap 100 gram bahan terdapat 39 kalori, protein 1,5 gr, hidrat arang 0,3 gr lemak $0,2 \mathrm{~g}$, kalsium $36 \mathrm{mg}$, fosfor $40 \mathrm{mg}$, besi $0,8 \mathrm{mg}$, dan vitamin $\mathrm{C} 2 \mathrm{gr}$.

Di sentra-sentra utama, komoditas ini diusahakan petani dari dataran rendah sampai dataran tinggi. Bawang merah menghendaki suhu udara berkisar antara $25^{\circ} \mathrm{C}-30^{\circ} \mathrm{C}$, tempat terbuka tidak berkabut, intensitas sinar matahari penuh, tanah gembur, subur cukup mengandung organik akan menghasilkan pertumbuhan dan produksi terbaik (Wibowo, 2006).

Berdasarkan Badan Pusat Statistik (BPS 2013) Impor bawang merah dari negara Eropa mencapai 2,755 ton senilai 13,3 milyar setiap bulan, sedangkan pada tahun 2012 (Januari-Desember) hanya 93 ribu ton dengan nilai 399 milyar (Detik.com, 2013). Tingginya permintaan komoditas bawang merah akhir-akhir ini karena ada hubungan meningkatnya jumlah penduduk, saat ini sering menjadi salah satu topik yang hangat untuk diperbincangkan karena bernilai ekonomis tinggi. Kenyataan ini menunjukkan bahwa pengembangan bawang merah masih terbuka lebar (Suriani, 2011), namun produksi yang diusahakan petani masih rendah, rata-rata 9,45 ton ha $^{-1}$ terutama Pulau Jawa (BPS, 2009), di luar Pulau Jawa, Sumatera, dan Sulawesi mencapai 8,05 ton ha ${ }^{-1}$ (Sinartani, 2013). Hasil penelitian Pardede et al. (2014), menjelaskan bahwa produksi bawang merah diantaranya dipengaruhi oleh pupuk. Salah satu alternatif yang dapat dilakukan untuk meningkatkan pertumbuhan dan produksi bawang merah adalah melakukan pemupukan secara tepat.

\section{BAHAN DAN METODE}

Berdasarkan permasalahan di atas perlu dilakukan suatu penelitian yang bertujuan meningkatan produksi bawang merah melalui $1 / 3$ bagian, dan $3 / 7$ bagian masuk ke dalam tanah. Setelah 1 minggu setelah tanam (MST) bawang merah dipupuk dengan NPK majemuk $5 \mathrm{gr}$ pot $^{-1}$, sistem melingkar, dan ditutup kembali dengan tanah sesuai jenis pupuk yang diberikan sebagai perlakuan. Pemupukan kedua dilakukan saat tanaman berumur 7 MST sebanyak $5 \mathrm{gr} \mathrm{pot}^{-1}$ dengan cara yang sama.

Pemeliharaan tanaman yang dilakukan meliputi penyulaman, penyiraman, pengen-dalian gulma, hama dan penyakit. Parameter yang diamati meliputi tinggi tanaman, jumlah daun atau rumpun, 
jumlah umbi atau rumpun, diameter umbi, panjang umbi, dan bobot basah umbi atau rumpun. Data yang terkumpul ditabulasikan dan dianalisa secara statistik menggunakan perangkat lunak SPSS ver 16 .

\section{HASIL DAN PEMBAHASAN}

Hasil analisis statistik menunjukkan bahwa pupuk NPK majemuk memberikan respon terhadap pertumbuhan vegetatif tanaman bawang merah. Data pada Tabel 1 mengindikasikan bahwa pemupukan NPK 18+9+10+Te; NPK $15+15+$ sulfat 10 dan NPK $15+9+20(\mathrm{~S})+2 \mathrm{MgO}+3,8 \mathrm{~S}+\mathrm{Te}$ tidak berbeda sesamanya meski berbeda dengan perlakuan lain dan terendah terdapat pada perlakuan kontrol. Meningkatnya partumbuhan tinggi tanaman diduga akibat tingginya kadar nitrogen yang diberikan pada pertanaman untuk pembentukan dan pertumbuhan sel. Selain itu adanya unsur hara mikro diduga juga berperan dalam meningkatkan penyerapan hara. Hal ini sesuai pendapat Napitupulu dan Winarno (2009) yang menyatakan bahwa pemberian nitrogen dapat meningkatkan pertumbuhan tanaman, merangsang pembentukan klorofil, dan menyebabkan warna daun lebih hijau, sehingga rasio pucuk akar bertambah. Karena itu pemberian nitrogen dapat meningkatkan laju pertumbuhan tanaman.

Tabel 1. Respon NPK terhadap Tinggi Tanaman Bawang Merah

\begin{tabular}{|c|c|c|c|c|c|c|c|}
\hline \multirow{2}{*}{ Perlakuan } & \multicolumn{7}{|c|}{ Tinggi Tanaman (MST) } \\
\hline & 2 & 3 & 4 & 5 & 6 & 7 & 8 \\
\hline NPK $18+9+10+T e$ & $21,6 a$ & 30,3 a & $48 \mathrm{a}$ & $54 \quad a$ & 55,6 a & 57,3 a & 59 \\
\hline NPK $15+15+15+$ sulfat & $19,6 \mathrm{a}$ & 25,4 bc & $42 \mathrm{c}$ & $48,3 \mathrm{~b}$ & $50 \mathrm{~b}$ & $55 \mathrm{~b}$ & 59 \\
\hline NPK & $22,1 \mathrm{a}$ & 31 a & $47 a b$ & $52 \mathrm{ab}$ & 55 & 56,3 a & $56,3 \mathrm{~b}$ \\
\hline $12+11+18+(\mathrm{S})+\mathrm{Mg}+\mathrm{Te}$ & & & & & & & \\
\hline NPK & $22,6 \mathrm{a}$ & $26 b c$ & $42 \mathrm{c}$ & $48,6 \mathrm{~b}$ & 53 & $53,3 \mathrm{c}$ & $58,7 \mathrm{a}$ \\
\hline $15+9+20(\mathrm{~S})+\mathrm{Mgo}+3 \mathrm{~S}+\mathrm{Te}$ & & & & & & & \\
\hline NPK $25+7+7$ & $17,6 \mathrm{~b}$ & $28,3 a b$ & $43 \mathrm{bc}$ & $48,3 \mathrm{~b}$ & $49,6 \mathrm{~b}$ & $56,6 \mathrm{ab}$ & $56 \mathrm{~b}$ \\
\hline Kontrol & $17,6 \mathrm{~b}$ & 24,7 bc & $43 \mathrm{bc}$ & $49,3 \mathrm{abc}$ & 54,6 a & $55,3 a b$ & $55,2 \mathrm{~b}$ \\
\hline
\end{tabular}

Keterangan : Angka pada kolom yang nilainya sama tidak berbeda nyata menurut uji DMRT jenjang $5 \%$

Nitrogen merupakan faktor pembatas utama pertumbuhan dan produksi tanaman. Nitrogen dibutuhkan tanaman selalu lebih tinggi dari hara lain, namun kekurangan atau kelebihan menghambat dan menganggu pertumbuhan tanaman. Tarigan et al. (2010) menyatakan nitrogen dibutuhkan dalam jumlah relatif besar pada setiap pertumbuhan tanaman khususnya pertumbuhan vegetatif tanaman, karena nitrogen merupakan bahan pembangun protein, asam nukleat, enzim, dan alkaloid. Dari hasil penelitian Nursyamsu et al. (1996), melaporkan peningkatan taka- ran nitrogen secara nyata dapat meningkatkan tinggi tanaman. Namun pemupukan nitrogen yang terlalu tinggi mengakibatkan kadar karbohidrat menurun dan tanaman tidak berkualitas (Hekl et al., (1972) cit, Rosmarkam, (2001)).

Hasil analisis statistika terhadap pertumbuhan jumlah daun dan anakan serta bobot kering brangkasan terdapat pada Tabel 2. Hasil analisis menunjukkan bahwa jumlah daun dan anakan perlakuan NPK $18+9+10+\mathrm{Te}$ berbeda nyata dengan perlakuan lain, namun jumlah daun antara perlakuan NPK $15+15+15+$ sulfat, NPK 
$25+7+7$ dan kontrol tidak berbeda. Demikian juga jumlah anakan perlakuan antara NPK 15+15+15+sulfat, NPK $15+9+20$ (S)+Mgo+3S+Te, NPK 25+7+7, dan kontrol jumlah daun terendah pada perlakuan NPK $12+11+18+(\mathrm{S})+\mathrm{Mg}+\mathrm{Te}$ dan NPK 15+9+20(S)+Mgo+3S+Te, sedangkan jumlah anakan terendah pada perlakuan NPK $12+11+18+(S)+M g+T e$. Tingginya jumlah daun dan anakan pada perlakuan NPK 18+9+10+Te, menunjukkan bahwa kadar nitrogen terdapat pada pupuk tersebut lebih tinggi dibanding lainnya kecuali pada perlakuan NPK $25+7+7$.

Tabel 2. Respon jumlah daun, jumlah anakan daun, bobot kering berangkasan bawang merah terhadap pupuk NPK majemuk dataran tinggi

\begin{tabular}{lccc}
\hline \multicolumn{1}{c}{ Perlakuan } & $\begin{array}{c}\text { Jumlah daun } \\
\text { atau rumpun }\end{array}$ & $\begin{array}{c}\text { Jumlah anakan } \\
\text { atau rumpun }\end{array}$ & Bobot kering \\
\hline NPK 18+9+10+Te & $74 \mathrm{a}$ & $25 \mathrm{a}$ & - -gr-- \\
NPK 15+15+15+sulfat & $57 \mathrm{ab}$ & $16,6 \mathrm{ab}$ & $3,0 \mathrm{a}$ \\
NPK 12+11+18+(S)+Mg+Te & $43,3 \mathrm{~b}$ & $14,3 \mathrm{~b}$ & $1,9 \mathrm{c}$ \\
NPK 15+9+20(S)+Mgo+3S+Te & $31 \mathrm{c}$ & $18,6 \mathrm{ab}$ & $2,5 \mathrm{~b}$ \\
NPK 25+7+7 & $58 \mathrm{ab}$ & $18,3 \mathrm{ab}$ & $2,4 \mathrm{~b}$ \\
Kontrol & $58,3 \mathrm{ab}$ & $17 \mathrm{ab}$ & $2,3 \mathrm{~b}$ \\
\hline
\end{tabular}

Keterangan : Angka pada kolom yang nilainya sama tidak berbeda nyata menurut uji DMRT jenjang $5 \%$

Nitrogen mampu meningkatkan jumlah daun dan anakan karena nitrogen merupakan salah satu unsur makro dibutuhkan tanaman sebagai bahan dasar utama membangun protein untuk pertumbuhan. Hal ini sesuai pendapat Gardner et al. (1991), nitrogen merupakan unsur hara yang dibutuhkan tanaman sebagai penyusun asam amino, amida, dan unsur esensial untuk merangsang pembelahan sel maupun pembesaran sel tanaman.

Pupuk NPK majemuk memberikan pengaruh terhadap bobot kering daun. Perlakuan A dan B berbeda nyata dengan perlakuan lain walaupun kedua perlakuan sama-sama tidak berbeda sedangkan terendah terdapat pada perlakuan $\mathrm{C}$. Tingginya bobot kering daun perlakuan $A$ dan B ada kaitannya dengan peranan nitrogen untuk meningkatkan pertumbuhan vegetatif. Hasil bobot kering menggambarkan kemampuan tanaman untuk menghimpun bahan organik selama pertumbuhan apabila sumbangan hara diabaikan, pertambahan bobot kering tersebut dinyatakan sebagai hasil dari reduksi karbon dioksida.

Semakin tinggi bobot kering yang dihasilkan tanaman, tidak akan selalu diikuti meningkatnya hasil produksi yang dicapai. Hal ini bertolak belakang dengan pendapat Guritno dan Sitompul (1995), yang menyatakan salah satu faktor pertumbuhan tanaman yang menentukan hasil adalah produksi biomassa tanaman. Hal ini menjelaskan bahwa pada satu sisi upaya peningkatan hasil dapat ditempuh melalui peningkatan produksi biomassa tanaman disamping peningkatan kapasitas lubuk yang merupakan sifat yang dikendalikan oleh faktor genetik dan tingkat alokasi biomassa ke bagian tanaman yang dipanen yang merupakan sifat fisiologis tanaman. Koefesien pembagian biomassa dianggap konstan khususnya untuk jenis tanaman tertentu dan 
kondisi lingkungan terbatas. Sekalipun koefesien pembagian biomassa berbeda, perbedaan hasil sebagian dapat juga disebabkan perbedaan produksi biomassa.

Tingginya jumlah daun dan anakan pada perlakuan A dibandingkan perlakuan lainnya, hal ini berkaitan peran nitrogen selain mampu merangsang dalam membentuk jumlah daun juga mampu membentuk anakan. Tanaman yang banyak memperoleh nitrogen warna daun lebih hijau tebal dan daun lebih luas sehingga proses fotosintesis mengalami peningka- tan. Hal ini sesuai dengan pendapat Englestad (1997), peran nitrogen sangat penting untuk pertumbuhan vegetatif terutama bagian daun bewarna lebih hijau, dapat meningkatkan rasio pucuk akar, dan mempengaruhi pembentukan buah dalam biji. Pupuk NPK majemuk memberikan respon terhadap diameter umbi dan panjang umbi, hal tersebut dapat dilihat pada data Tabel 3, yang menunjukkan bahwa Perlakuan $\mathrm{C}$ berbeda nyata dengan perlakuan lainnya.

Tabel 3. Respon diameter, panjang umbi, dan bobot basah bawang terhadap pupuk NPK majemuk

\begin{tabular}{lccc}
\hline \multicolumn{1}{c}{ Perlakuan } & Diameter umbi & Panjang umbi & Bobot basah umbi \\
\hline NPK 18+9+10+Te & $17,2 \mathrm{~b}$ & $23 \mathrm{c}$ & $450 \mathrm{ab}$ \\
NPK $15+15+15+$ sulfat & $19,5 \mathrm{ab}$ & $26,6 \mathrm{ab}$ & $420 \mathrm{ab}$ \\
NPK $12+11+18+(\mathrm{S})+$ Mg+Te & $22,3 \mathrm{a}$ & $30,5 \mathrm{a}$ & $510 \mathrm{a}$ \\
NPK 15+9+20(S)+Mgo+3S+Te & $19,6 \mathrm{ab}$ & $26,4 \mathrm{ab}$ & $470 \mathrm{ab}$ \\
NPK 25+7+7 & $21,6 \mathrm{a}$ & $26,8 \mathrm{ab}$ & $475 \mathrm{ab}$ \\
Kontrol & $17,6 \mathrm{~b}$ & $24,6 \mathrm{~b}$ & $340 \mathrm{~b}$ \\
\hline
\end{tabular}

Keterangan : Angka pada kolom yang nilainya sama tidak berbeda nyata menurut uji DMRT jenjang $5 \%$

Meningkatnya ukuran panjang dan diameter umbi bawang merah pada perlakuan $\mathrm{C}$ diduga karena kadar kalium jumlahnya cukup tinggi dari pada perlakuan $A, B$, dan $E$ namun lebih rendah dari perlakuan E. Hal tersebut diduga karena kadar kalium pada perlakuan $\mathrm{C}$ ukuran jumlah paling tepat dan ideal dari lainnya, sehingga sesuai untuk memenuhi kebutuhan tanaman.

Pentingnya tanaman terhadap kalium karena unsur tersebut mampu mensintesa protein untuk merangsang pembentukan umbi lebih sempurna. Hal ini sesuai pendapat Gardner et al. (1991), kalium mempunyai peranan penting dalam proses fotosintesis secara langsung, mampu meningkatkan pertumbuhan dan indek luas daun disamping mempunyai fungsi untuk meningkatkan asimilasi $\mathrm{CO}$, juga dapat meningkatkan translokasi hasil fotosintesis keluar daun (ke jaringan lain yang membutuhkan). Tanaman cenderung mengambil kalium dalam jumlah yang lebih banyak dari yang dibutuhkan tetapi tidak menambah produksi (Hardjodwigino, 2003).

Pupuk NPK majemuk yang mengandung magnesium ( $\mathrm{Mg}$ ) diduga mampu meningkatkan panjang dan diameter umbi lebih baik, sebab magnesium mempunyai peran dalam mengaktifkan enzim yang berkaitan dengan metabolisme karbohidrat, enzim pernapasan, dan juga bekerja sebagai katalisator. Disamping itu magnesium berfungsi sebagai kofaktor dalam enzim terutama yang mengaktifkan proses fosforilase (Rosmarkam, 2001). Magnesium yang terkandung dalam pupuk merupakan kelat dalam kloroplas. Magnesium mem- 
bentuk kelat dengan ADP, ATP, dan asam organik, oleh karena itu magnesium penting untuk mengatur ratusan reaksi enzim. Hal ini sesuai pendapat Gardner (1991), yang menyatakan metabolisme nitrogen dan sintesis protein tergantung adanya unsur magnesium dan diperkirakan Mg menunjang integritas ribosom tanaman.

Hara mikro dibutuhkan tanaman sangat sedikit dibandingkan hara sekunder, namun perannya sangat penting untuk tanaman. Hal ini sesuai dengan pendapat Gardner (1991), untuk mendukung pertumbuhan dan produksi, tanaman membutuhkan hara mikro yang jumlahnya sangat kecil tetapi perannya sangat penting untuk meningkatkan aktivitas enzim dan transport elektron dalam proses fotosintesis. Hara mikro diperlukan tanaman relatif sedikit dari pada hara sekunder (Mori, (1999) cit Subhan et al. (2008)).

Bobot basah umbi bawang dipengaruhi pupuk NPK majemuk. Perlakuan $\mathrm{C}$ memberikan bobot basah tertinggi (berbeda nyata dengan perlakuan lain), namun perlakuan antara $A, B, D$, dan E tidak berbeda sesama, sedangkan terendah tanpa perlakuan atau kontrol. Tingginya bobot basah perlakuan $\mathrm{C}$ diduga karena peran unsur $\mathrm{Mg}$ dan unsur mikro yang terdapat dalam pupuk sangat penting. Diduga Pupuk NPK majemuk akan ideal, berimbang, dan lebih bermanfaat bila ditambah unsur magnesium dan unsur mikro, hal tersebut terbukti tanaman yang dipupuk perlakuan $\mathrm{C}$ mengasilkan bobot basah umbi lebih tinggi dari lainnya.

Komponen hasil panen panjang dan diameter umbi pada perlakuan $\mathrm{C}$ lebih baik ukurannya, hasil umbi lebih berisi, bernas (padat), dan warna lebih merah, serta seimbang ukuran antara panjang dan diameter umbi sehingga mempengaruhi terhadap produksi. Diduga selain unsur $\mathrm{Mg}$ dan unsur mikro komposisi kandungan pupuk antara $\mathrm{N}$ dan $\mathrm{P}$ lebih ideal dan seimbang walaupun kalium tergolong tinggi, namun sesuai kebutuhan tanaman mudah memanfaatkan secara baik. Hal ini sesuai pendapat Subhan et al. (2008), setiap unsur hara yang terkandung di dalam pupuk NPK majemuk saling mendukung untuk berbagai proses metabolisme sel, fotosintesis, dan respirasi sel tanaman sehingga dapat meningkatkan hasil buah tomat.

\section{KESIMPULAN}

Pupuk NPK majemuk $12+11+18+(\mathrm{S})+$ $\mathrm{Mg}+\mathrm{Te}$ merupakan pupuk yang lebih baik pengaruhnya terhadap pertumbuhan dan produksi bawang merah varietas Mentes dataran tinggi, layak digunakan untuk tanaman bawang merah varietas mentes dataran tinggi.

\section{DAFTAR PUSTAKA}

Afandie, Rosmarkam. 2001. Ilmu Kesuburan Tanah. Jurusan Ilmu Tanah Fakultas Pertanian UGM Yokyakata.

Badan Pusat Statitik (BPS). 2009. Survei Pertanian Statistik tanaman sayuran dan buah. Agriculture Survay Statistik of vegetable and fruit plant Indonesia 2007. Badan Statistik Jakarta Indonesia.

Englestad. 1997. Teknologi Penggunaan Pupuk. UGM Press Yogyakarta.

Napitupulu, D. dan Winarno. 2009. Pengaruh Pemberian pupuk $\mathrm{N}$ dan $\mathrm{K}$ 
terhadap pertumbuhan dan produksi Bawang merah. Jurnal Hortikultura, Badan Penelitian dan Pengembangan Pertanian Pusat Penelitian dan Pengembangan Hortikultura Jakarta Indonesia.

Nursyamsu, Adiningsih, Soleh, dan Adi, 1996. Penggunaan Bahan Organik Untuk Meningkatkan Efisiensi Pupuk $\mathrm{N}$ dan Produktifitas Tanah Ultisol di Sitiung Sumbar.

Rosliani, R,Y. Hilman dan Sumarni. 2006. Pemupukan pospat alam pupuk kandang domba dan inokulasi cendawan mikoriza arbuskar terhadap pertumbuhan dan hasil timun pada tanah masam. Jurnal Hortikultura. Badan Litbang Pertanian. Pusat Penelitian dan Pengembangan Hortikultura Jakarta Indonesia

Samadi, Budi dan Bambang Cahyono. 2005. Seri Budidaya Bawang Merah Intensifikasi Usahatani. Penerbit Kanisius: Yogyakarta.
Silalahi, F.H,A.E. Marpaung, dan R. Tarigan. 2010. Tanggap Pertumbuhan Tanaman Biwa terhadap Bergagai Perbandingan Dosis Pupuk NPK.

Singgih, Wibowo. 2006. Seri Agribisnis Budidaya Bawang, Bawang Putih, Bawang Merah, Bawang Bombay. Penebar Swadaya.

Subhan, N. Nurtika,dan N. Gunadi 2008. Respon tanaman tomat terhadap penggunaan pupuk Majemuk NPK 15:15:15 pada tanah latosol musim kemarau. Jurnal Hortikultura. Badan Penelitian dan Pengembangan Pertanian. Pusat Penelitian Pengembangan Hortikultura Jakarta: Indonesia

Suriani, N., 2011. Bawang Bawa Untung. Budidaya Bawang Merah. Cahaya Atma Pustaka Yogyakarta.

Sinar Tani. 2013. Membangun kemandirian Agribisnis. Tabloid Edisi 27 Maret tanggal 2 April 2013 no. 3500 XLII. 